\title{
Metalloproteomic and differential expression in plasma in a rat model of type 1 diabetes
}

\author{
Camila Pereira Braga ${ }^{\mathrm{a}, *}$, José Cavalcante Souza Vieira ${ }^{\mathrm{a}}$, Aline de Lima Leite ${ }^{\mathrm{b}}$, \\ Ana Angélica Henrique Fernandes ${ }^{\mathrm{a}}$, Marília Afonso Rabelo Buzalaf ${ }^{\mathrm{b}}$, \\ Pedro de Magalhães Padilha ${ }^{a}$ \\ a Department of Chemistry and Biochemistry, Institute of Bioscience, São Paulo State University (UNESP), Botucatu, SP, Brazil \\ b Bauru Dental School, University of São Paulo - USP, Bauru, SP, Brazil
}

\section{A R T I C L E I N F O}

\section{Article history:}

Received 31 October 2016

Received in revised form 1 May 2017

Accepted 6 June 2017

Available online 8 June 2017

\section{Keywords:}

Differential proteomic

Metalloproteomic

Type 1 diabetes

\begin{abstract}
A B S T R A C T
Type 1 diabetes is characterized by hyperglycemia, which in the chronic stage is associated with abnormalities in lipids, protein and, carbohydrate metabolism, as well as oxidative stress. New strategies for prevention and treatment are needed, as type 1 diabetes affects life quality and survival, and involves high-cost treatment. Proteomic and metalloproteomic studies can elucidate the functional and physiological aspects of biomolecules. In the present study, differential proteomics was used to identify potential biomarkers of diabetes in rat plasma associated with copper, selenium, zinc, and magnesium fractionation in control and diabetic rats, as well as diabetic rats treated with insulin. 2D-PAGE was used in the plasma protein fractionation; graphite furnace atomic absorption spectrometry (GFAAS) and flame atomic absorption spectrometry (FAAS) were used for quantitative determination of copper, magnesium, selenium, and zinc in the spots that showed different expression; and protein spots were characterized by electrospray ionization-tandem mass spectrometry (ESI-MS/MS) after tryptic digestion. ESI-MS/MS analysis characterized 35 different proteins, indicating alpha-1-macroglobulin and haptoglobulin as potential candidates as biomarkers for diabetes treated with insulin; also, 2'-deoxynucleoside 5'-phosphate $N$ hydrolase 1, transmembrane protein 11, serum amyloid P component, vitamin D-binding protein, and biliverdin reductase were identified as potential candidates as biomarkers for uncontrolled diabetes.
\end{abstract}

(C) 2017 Elsevier B.V. All rights reserved.

\section{Introduction}

Diabetes mellitus type 1 (DM1) is a chronic autoimmune disease of pancreatic $\beta$-cell destruction, resulting in an ongoing state of insulin deficiency [1]. The rate of pancreatic $\beta$-cell destruction is variable, being rapid in children and adolescents and mainly slow in adults [2]. DM1 is one of the most common chronic diseases of childhood [3], occurring between 5 and 7 years of age and also close to puberty [4]. Studies suggest that most patients with longstanding DM1 have $\beta$-cell regeneration in early childhood, but not in adolescence or adulthood [5].

Studies have shown different protein profiles obtained from serum and plasma [6,7]. It is difficult to decide between serum or plasma as preferable for use in proteomic studies with biomarker

\footnotetext{
* Corresponding author. Current address: Department of Chemistry and Biochemistry - Institute of Biosciences of Botucatu, São Paulo State University (UNESP), Rubião Júnior, Botucatu, SP, 18618-970, Brazil.

E-mail address: braga_ca@ibb.unesp.br (C. Pereira Braga).
}

focus [8], but plasma seems to be more stable than serum [8]. Plasma is the most varied sample of the proteome present in the body; the protein profiles of plasma vary with physiological and pathological conditions [9]. Proteomics has been used to reflect clinically relevant molecules in the blood due to specific diseases [10]. The objectives of the use of proteomics in plasma are as follows: elimination of the need for biopsy, diagnosis of specific diseases (using proteins as biomarkers), understanding the pathogenesis of disease, and monitoring the progress of therapeutic interventions. This is due to the urgent need to identify molecular targets (functional proteome) for early diagnosis and effective treatment of disease [11].

The interaction between a causative agent and the organism may modify various biological parameters. Several studies have involved comparing the biomarker protein pattern present in a healthy sample with that of an affected sample because proteins play crucial roles in biological systems (specific activities associated with other biomolecules, where their expression levels are essential for optimal performance of cellular functions) [12]. The 
diagnosis of primary and secondary complications of DM1 using biomarkers will help to prevent secondary complications of diabetes and thus reduce the severity of the disease.

On the other hand, one-third of all proteins possess a bound metal [13]. Metalloproteins involve diverse classes of proteins, with intrinsic metal atoms providing different functions (catalytic, regulatory, and structural) [14]. Metalloproteomes are investigated by a combination of approaches: annotation of a protein and identification of the intrinsic metal, and bioinformatics analysis [14]. The Protein Data Bank shows that the most abundant are magnesium $(\mathrm{Mg})$ and zinc $(\mathrm{Zn})$, and calcium (Ca), manganese (Mn), iron (Fe), and nickel (Ni) are frequently observed [13].

DM1 causes metabolic and functional alterations which can alter the proteome and metalloproteome; the comparative metalloproteome has not been reported in the literature involving DM1. In this context the present study involves the study of differential protein expression in diabetic rat plasma following fractionation by two-dimensional electrophoresis (2D PAGE) and identification by electrospray ionization-tandem mass spectrometry (ESI-MS/MS) followed by $\mathrm{Cu}, \mathrm{Se}$, and $\mathrm{Zn}$ investigation of these spots by graphite furnace atomic absorption spectrometry (GFAAS) and of Mg by flame atomic absorption spectrometry (FAAS).

\section{Material and methods}

\subsection{Experimental animals}

The experimental procedures were approved by the Ethics Committee on the Use of Animals (CEUA) of the Institute of Biosciences/São Paulo State University (UNESP) - Botucatu, which were in accordance with the ethical principles in animal research provided by the Brazilian College of Animal Experimentation (protocol: CEUA-436/2012).

The animals used were male Wistar rats ( $\mathrm{n}=24$, Rattus norvegicus) with an average initial weight of approximately $250 \mathrm{~g}$ and age of 45 days; these were kept in individual plastic cages under controlled temperature $\left(25 \pm 2{ }^{\circ} \mathrm{C}\right)$ and photoperiod $(12: 12 \mathrm{~h}$ light/dark cycle) conditions. The animals received water and commercial diet (Purina Labina, Campinas, SP) ad libitum throughout the experimental period. Water and food intake was controlled daily and weighing of the animals was performed weekly.

The animals were randomly assigned to the following experimental groups ( $n=8$ per group): $C$ (control) - normal rats which received water and food, DM1 (diabetic rats) - diabetic rats which received water and food and DM1 + I (diabetic rats treated with insulin) - diabetic rats treated with insulin replacement, which received water and food. Experimental DM1 was induced by the intraperitoneal administration of streptozotocin (STZ, single dose, $60 \mathrm{mg} \mathrm{kg}^{-1}$ body weight). The STZ was diluted with sodium citrate buffer $(0.1 \mathrm{M}, \mathrm{pH} 4.5)$ and the animals received $1 \mathrm{~mL}$ of the prepared solution. Those animals with glucose concentrations above $220 \mathrm{mg} \mathrm{dL}^{-1}$ were considered diabetic and used in the experiment. The DM1 + I group received insulin replacement at an initial dose of 3U/animal (subcutaneously) of Humulin N100UI neutral protamine Hagedorn (NPH), Lilly brand. The blood glucose values were checked daily and the initial insulin dose was adjusted or maintained to obtain normal glucose levels ( $\left.110 \mathrm{mg} \mathrm{dL}^{-1}\right)$.

At the end of the 30-day experimental period, the animals were anaesthetized (ketamine hydrochloride $10 \%, 0.1 \mathrm{~mL} / 100 \mathrm{~g}$ body weight, i.p.) and sacrificed by decapitation. The blood was collected in the presence of heparin, and the plasma was separated by centrifugation for $15 \mathrm{~min}$ at $6000 \times \mathrm{g}$.

\subsection{Biochemical determinations}

Blood glucose was determined using the method of Moura et al. [15], in which the staining intensity is proportional to the glucose concentration in the sample; this was performed prior to the pooling of plasma samples in order to verify that the animals in the DM1 group presented hyperglycemia and that the DM1 animals were able to achieve normoglycemia with insulin replacement, thus ensuring that the animals used in the experiment reproduced the pathological findings typical of DM1 and responded appropriately to insulin therapy. Having made this determination from the individual glucose concentrations of these animals, $n=8$ animals were selected for each experimental group in order to pool plasma samples for each group.

The total protein concentration in rat plasma samples was determined by the Biuret method using bovine serum albumin as standard. Analytical calibration curves were constructed with concentrations of $10-100 \mathrm{gL}^{-1}$ from a stock solution of albu$\min \left(100 \mathrm{~g} \mathrm{~L}^{-1}\right)$. The method used $50 \mathrm{~mL}$ of sample for standards and $2.5 \mathrm{~mL}$ of Biuret reagent, which were mixed and placed in a water bath at $37^{\circ} \mathrm{C}$ for $10 \mathrm{~min}$. After $5 \mathrm{~min}$ at room temperature, absorbance readings were performed in a spectrophotometer at a wavelength of $545 \mathrm{~nm}$.

\subsection{Electrophoretic separation of protein fractions}

Six gels were made for each group (pooled plasma), resulting in a total of 18 gels. To retain the solubilized proteins, aliquots of pooled plasma were diluted in urea solution containing $7 \mathrm{~mol} \mathrm{~L}^{-1}$, thiourea 2 mol L $^{-1}$, CHAPS (3-[(3-chloroaminopropyl)-dimethylammonio]1-propane sulfate) $2 \%(\mathrm{w} / \mathrm{v})$, ampholytes $0.5 \%(\mathrm{v} / \mathrm{v})$ at $\mathrm{pH}$ ranging from 4 to 7 , and $0.002 \%$ bromophenol blue (w/v); $2.8 \mathrm{mg}$ of DTT (1,4-dithiothreitol) (GE Healthcare) was then added to this buffer. Dilution of the plasma pool was made in such a way that the resulting concentration of total proteins in the rehydration solution was the same for all samples. Prior to the electrophoretic separation process, a mass of $375 \mu \mathrm{g}$ of rat plasma proteins was applied to $13 \mathrm{~cm}$ strips for isoelectric focusing; these strips contained a precast gel with immobilized ampholytes at pH 4-7 (GE Healthcare). These strips were placed in the apparatus and allowed to stand for $12 \mathrm{~h}$ at room temperature to allow rehydration of the protein extract. After this period, the rehydrated strip was taken to the isoelectric focusing system (Ettan ${ }^{\mathrm{TM}}$ IPGphor ${ }^{\mathrm{TM}}$, GE Healthcare Life Sciences) for isoelectric focusing in the first dimension, which was performed for a total of $18,000 \mathrm{Vh}$.

After separation in the first dimension, the strip proteins, which had been separated according to pI, were equilibrated in two steps. First, we used $10 \mathrm{~mL}$ of solution containing urea $6 \mathrm{~mol} \mathrm{~L}^{-1}$, SDS (sodium dodecyl sulfate) $2 \%(\mathrm{w} / \mathrm{v}), 30 \%$ glycerol $(\mathrm{v} / \mathrm{v})$, Tris- $\mathrm{HCl}$ $50 \mathrm{mmol} \mathrm{L}^{-1}$ ( $\left.\mathrm{pH} 8.8\right), 0.002 \%$ bromophenol blue (w/v), and $2 \%(\mathrm{w} / \mathrm{v})$ DTT, in order to keep the proteins in their reduced forms. The second stage used a solution of similar composition, substituting DTT for iodoacetamide (IAA) $2.5 \%(\mathrm{w} / \mathrm{v}$ ) to obtain alkylation of the protein thiol groups and thus prevent possible reoxidation. Each step lasted for $15 \mathrm{~min}$ and was performed under low agitation on a table. In the second step of the electrophoretic (SDS-PAGE) process, the strips were applied to polyacrylamide gels at $10 \%(\mathrm{w} / \mathrm{v})$, previously prepared between $180 \times 160 \times 1.5 \mathrm{~mm}$ plates. We applied the molecular mass standards (12-225 kDa) to the side of the strip, and both were sealed with an agarose solution $(0.5 \% \mathrm{w} / \mathrm{v})$; the run was done in two steps: $7.5 \mathrm{~mA} /$ gel at $30 \mathrm{~min}$ and $15 \mathrm{~mA} /$ gel at $6 \mathrm{~h} 10 \mathrm{~min}$.

After the running period, the proteins in the gel were fixed for $1 \mathrm{~h}$ using a solution containing $10 \%$ acetic acid (v/v) and $40 \%(\mathrm{v} / \mathrm{v})$ ethanol. Proteins were visualized by employing colloidal Coomassie stain, and the gel was scanned and the image analyzed using ImageMaster Platinum image processing software version 7.0 to obtain 
Table 1

Body weight (g, initial and final), glucose ( $\mathrm{mg} \mathrm{dL}^{-1}$; initial and final) feed intake ( $\mathrm{g} /$ day), and water consumption ( $\mathrm{mL} /$ day) for the different experimental groups.

\begin{tabular}{|c|c|c|c|}
\hline & $\mathrm{C}$ & DM1 & DM1 + I \\
\hline Initial weight (g) & $298.56 \pm 10.59 a$ & $295.47 \pm 15.34 a$ & $288.52 \pm 18.06 a$ \\
\hline Final weight (g) & $371.66 \pm 14.68 \mathrm{a}$ & $234.91 \pm 34.86 b$ & $341.82 \pm 17.93 a$ \\
\hline Initial glucose $\left(\mathrm{mg} \mathrm{dL}^{-1}\right)$ & $108.88 \pm 10.88 \mathrm{a}$ & $101.29 \pm 19.38 a$ & $104.17 \pm 4.17 \mathrm{a}$ \\
\hline Final glucose $\left(\mathrm{mg} \mathrm{dL}^{-1}\right)$ & $110.29 \pm 23.73 a$ & $427.97 \pm 40.34 b$ & $126.02 \pm 15.03 a$ \\
\hline Feed intake (g/dia) & $25.93 \pm 2.01 \mathrm{a}$ & $44.44 \pm 8.55 b$ & $27.68 \pm 7.12 \mathrm{a}$ \\
\hline Water cosnumption (mL/dia) & $33.66 \pm 3.62 a$ & $161.34 \pm 20.88 b$ & $51.96 \pm 14.51 \mathrm{a}$ \\
\hline
\end{tabular}

All values are expressed as means \pm SD. ${ }^{\mathrm{a}, \mathrm{b}, \mathrm{c}}$ Means followed by different letters indicate significant differences between the groups $(p<0.05$ ).

the following program parameters: number of spots, percentage of matching between gels, pI, and molecular mass of spots.

\subsection{Analysis of differential expression}

To determine the statistical significance between the spots, the normalized volume $(\% \mathrm{~V})$ was used and analysis of variance (ANOVA) was performed using ImageMaster Platinum software version 7.0. The significance level adopted was $5 \%$.

\subsection{Protein spot characterization by ESI-MS/MS}

The protein spots were extracted from the gels and prepared for MS according to Shevchenko et al. [16] with some modifications, using the following steps: stain removal, reduction and alkylation of proteins, trypsin digestion, and elution of peptides. The solution containing peptides was analyzed by obtaining mass spectra using a nanoACQUITY UPLC-Xevo QT-MS (Waters, Manchester, UK) system. The scan range was 50-2000 Da, and the data was acquired over $20 \mathrm{~min}$. ProteinLynx Global Server (PLGS) version 3.0 was used to process and search the continuum LC-MS ${ }^{\mathrm{E}}$ data, setting carbamidomethylation of cysteines as the fixed modification and oxidation of methionines as the variable modification, allowing one missing cleavage and a maximal error tolerance of $10 \mathrm{ppm}$ [17].

Protein identification was obtained with the embedded ion accounting algorithm of the software and searching in the Rattus norvegicus database (UniProtKB/Swiss-Prot at www.uniprot. org). Some parameters commonly used in ESI-MS/MS are shown in Table 2 such as the protein accession number, the identification used in the database (UniProtKB/Swiss-Prot at www.uniprot.org); the protein score is derived from the ion scores and for a search that contains a small number of queries is the sum of the highest ion score for each distinct sequence; the protein $\mathrm{pI}$ and Mw experimental are obtained in the Platinum ImageMaster software for each gel run; the protein $\mathrm{pI}$ and Mw theoretical are obtained in the database for each protein using the protein accession number (UniProtKB/Swiss-Prot at www.uniprot.org); and coverage is used to determine the percentage of the residues in each protein sequence that have been identified. FASTA sequences of the detected proteins were obtained and imported into the Blast2GO program (B2G), which enabled separation into two levels (cellular component and molecular function) [18].

\section{6. $\mathrm{Cu}, \mathrm{Mg}$, Se, and Zn mapping by FAAS or GFAAS}

The protein spots identified with differential expression were analyzed by GFAAS and FAAS after mineralizing the samples (spots, feed, and total plasma) as described by Moraes et al. [19]. We used two different electrophoretic runs, and $\mathrm{Cu}, \mathrm{Mg}$, Se, and $\mathrm{Zn}$ determinations were performed with a Shimadzu AA-6800 atomic absorption spectrometer using wavelengths of $324.7 \mathrm{~nm}, 285.2 \mathrm{~nm}$, $190.0 \mathrm{~nm}$, and $213.9 \mathrm{~nm}$, respectively. The current used for $\mathrm{Cu}, \mathrm{Se}$, and $\mathrm{Zn}$ determinations was $400 \mathrm{~mA}$ and $10 \mathrm{~mA}$ was used for $\mathrm{Mg}$, using curves with concentration ranges $5.00-20.00 \mu \mathrm{g} \mathrm{L}^{-1}$ for $\mathrm{Cu}$ and $\mathrm{Zn} ; 0.10-0.40 \mathrm{mg} \mathrm{L}^{-1}$ for $\mathrm{Mg}$, and $10.00-60.00 \mu \mathrm{g} \mathrm{L}^{-1}$ for Se. The region of the gel where no protein spots appeared was used as the analytical blank. The limits of quantification (LOQ) of $\mathrm{Cu}, \mathrm{Mg}$, Se, and $\mathrm{Zn}$ were $0.046 \mu \mathrm{g} \mathrm{L}^{-1}, 0.94 \mu \mathrm{g} \mathrm{L}^{-1}, 0.083 \mu \mathrm{g} \mathrm{L}^{-1}$ and $0.023 \mu \mathrm{gL}^{-1}$, respectively.

\subsection{Statistical analyses}

For biochemical and nutritional variables, a completely randomized design was used according to ANOVA. The level of significance for statistical analyses was $\alpha=0.05$ and $F$ statistics were significant at $p<0.05$. Tukey's test was used to compare means between groups [20].

\section{Results and discussion}

\subsection{Analysis of experimental groups}

Animals were chosen to compose the results set on the basis of glycemic analysis of experimental groups, associated with weight loss/gain and symptoms observed, such as polyuria and polyphagia, over the 30 experimental days (Table 1 ).

After the induction of experimental diabetes, it was noted that the DM1 animals had lower $(p<0.05)$ final body weight compared with the other experimental groups ( $C$ and DM1+I), which did not differ from each other. This indicates a greater weight loss in untreated diabetic animals compared with groups C and DM1+I. Weight loss, which is commonly observed in DM1, is one of the most common manifestations and may result either from excessive protein degradation or high lipolysis [21]. The final glucose concentrations in untreated diabetic rats (DM1) showed a significant increase when compared with the other groups (C and DM1 + I). The hyperglycemia observed in DM1 may have been due to low peripheral glucose utilization or abnormalities in glucose metabolism, in particular, activation of gluconeogenesis and glycogenolysis [22].

DM1 animals showed symptoms of polyuria and polyphagia. An increase in both feed and water intake was noted for DM1 animals compared with C and DM1 + I animals, which did not differ from each other. The increase in food consumption in DM1 could have been related to the availability of intracellular glucose molecules and also to high glycosuria [23], whereby water intake is high due to brisk diuresis because the glucose concentration in the glomerular filtrate is increased due to hyperglycemia. With insulin replacement in DM1 + I animals, there was an improvement in the above-mentioned parameters, such as increased weight gain and reduced food, water, and glucose consumption; this may be attributed to improved glycemic control.

The results for the protein concentration obtained by the Biuret method, in $\mathrm{gL}^{-1}$, were as follows: $\mathrm{C}=61.70$, DM $1=55.60$, and $\mathrm{DM} 1+\mathrm{I}=58.50$. Based on the results of the total protein present in rat plasma samples, the amount to be added in the hydration steps prior to isoelectric focusing (separation of proteins by isoelectric point) was calculated. 
Table 2

Characterisation of protein spots that showed differential expression $(p<0.05)$ by ESI-MS/MS. Positive and negative values indicate up or down abundance of proteins in relation to the spot analysed.

\begin{tabular}{|c|c|c|c|c|c|c|c|}
\hline Spot ID & Protein & Access & Score & $\mathrm{pl} / \mathrm{Mw}$ experimental & $\mathrm{pl} / \mathrm{Mw}$ theoretical & Coverage (\%) & $\mathrm{p}<0.05$ \\
\hline \multirow[t]{2}{*}{$1(-\mathrm{C} /+\mathrm{DM} 1)$} & Histidine-rich glycoprotein & HRG_RAT & 507 & $5.08 / 63,445$ & $7.76 / 59,049$ & 8 & 0.035 \\
\hline & Plasma protease $\mathrm{C} 1$ inhibitor & IC1_RAT & 460 & & $5.53 / 55,611$ & 14.68 & \\
\hline $2(+\mathrm{C} /-\mathrm{DM} 1)$ & Small kinetochore-associated protein & SKAP_RAT & 65 & $4.84 / 48,794$ & $5.33 / 34,885$ & 6.09 & 0.035 \\
\hline $3(+\mathrm{C} /-\mathrm{DM} 1)$ & Alpha-1-antiproteinase & A1AT_RAT & 1882 & $5.11 / 48,093$ & $5.70 / 46,136$ & 7.79 & 0.038 \\
\hline $4(+\mathrm{C} /-\mathrm{DM} 1)$ & Alpha-1-antiproteinase & A1AT_RAT & 1078 & $5.20 / 48,100$ & $5.70 / 46,136$ & 12.41 & 0.007 \\
\hline \multirow{2}{*}{$5(-C /+D M 1)$} & Transmembrane protein 11 , mitochondrial & TMM11_RAT & 124 & $5.21 / 52,609$ & $6.98 / 21,342$ & 3.68 & 0.014 \\
\hline & 2'-deoxynucleoside 5'-phosphate $\mathrm{N}$-hydrolase 1 & DNPH1_RAT & 102 & & $4.95 / 17,781$ & 9.82 & \\
\hline $6(-C /+D M 1)$ & Serum albumin & ALBU_RAT & 740 & $5.89 / 35,808$ & $6.09 / 68,731$ & 8.72 & 0.016 \\
\hline 7 (+C/-DM1) & Alpha-1-antiproteinase & A1AT_RAT & 94 & $5.97 / 32,346$ & $5.70 / 46,136$ & 3.67 & 0.029 \\
\hline $8(-C /+D M 1)$ & Haptoglobin & HPT_RAT & 474 & $6.03 / 30,236$ & $6.10 / 38,563$ & 8.07 & 0.019 \\
\hline \multirow[t]{3}{*}{$9(-\mathrm{C} /+\mathrm{DM} 1)$} & Fibrinogen beta chain & FIBB_RAT & 751 & $6.72 / 48,687$ & $7.89 / 54,235$ & 16.28 & 0.013 \\
\hline & Ig gamma-1 chain $\mathrm{C}$ region & IGHG1_RAT & 184 & & $6.43 / 35,946$ & 4.91 & \\
\hline & Taste receptor type 2 member 114 & TR114_RAT & 54 & & $9.27 / 35.604$ & 3.24 & \\
\hline \multirow[t]{2}{*}{$10(-\mathrm{C} /+\mathrm{DM} 1)$} & Galanin peptides & GALA_RAT & 112 & $6.05 / 20,170$ & $5.76 / 13,328$ & 18.55 & 0.040 \\
\hline & Protein phosphatase 1 regulatory subunit 11 & PP1RB_RAT & 84 & & $6.21 / 13,936$ & 24.41 & \\
\hline $11(-\mathrm{C} /+\mathrm{DM} 1)$ & Ig kappa chain $C$ region, A allele & KACA_RAT & 257 & $5.38 / 21,296$ & $4.99 / 11,732$ & 28.3 & 0.048 \\
\hline $12(+\mathrm{C} /-\mathrm{DM} 1)$ & Serum amyloid P-component & SAMP_RAT & 593 & $4.92 / 23,098$ & $5.50 / 26,176$ & 16.23 & 0.047 \\
\hline $13(-\mathrm{C} /+\mathrm{DM} 1)$ & Neutrophil cytosol factor 2 & NCF2_RAT & 13 & $4.56 / 23,453$ & $5.67 / 59,573$ & 2.66 & 0.035 \\
\hline \multirow{2}{*}{$14(-\mathrm{C} /+\mathrm{DM} 1)$} & Vitamin D-binding protein & VTDB_RAT & 535 & $5.48 / 51.551$ & $5.65 / 53,544$ & 2.94 & 0.049 \\
\hline & Biliverdin reductase $\mathrm{A}$ & BIEA_RAT & 135 & & 33,566 & 13.56 & \\
\hline $15(+C /-D M 1+I)$ & Afamin & AFAM_RAT & 145 & $5.11 / 72,357$ & $5.87 / 69,335$ & 12.5 & 0.026 \\
\hline $16(-\mathrm{C} /+\mathrm{DM} 1+\mathrm{I})$ & Serotransferrin & TRFE_RAT & 154 & $4.99 / 68,771$ & $7.14 / 76,395$ & 2.58 & 0.011 \\
\hline $17(-\mathrm{C} /+\mathrm{DM} 1+\mathrm{I})$ & Serotransferrin & TRFE_RAT & 378 & $5.05 / 68,468$ & $7.14 / 76,395$ & 10.89 & 0.015 \\
\hline $18(+\mathrm{C} /-\mathrm{DM} 1+\mathrm{I})$ & Hemopexin & HEMO_RAT & 1078 & $5.20 / 48,100$ & $7.58 / 51,351$ & 14.78 & 0.001 \\
\hline $19(+C /-D I)$ & Serum albumin & ALBU_RAT & 245 & $6.30 / 59,343$ & $6.09 / 68,731$ & 8.72 & 0.005 \\
\hline \multirow[t]{2}{*}{$20(-\mathrm{C} /+\mathrm{DM} 1+\mathrm{I})$} & Serine protease inhibitor A3L & SPA3L_RAT & 252 & $4.95 / 56,047$ & $5.48 / 46,277$ & 7.26 & 0.018 \\
\hline & Serine protease inhibitor 2.1 & SPI21_RAT & 251 & & $6.83 / 24,218$ & 11.21 & \\
\hline $21(-\mathrm{C} /+\mathrm{DM} 1+\mathrm{I})$ & Alpha-1-macroglobulin & A1M_RAT & 574 & $5.05 / 56,000$ & $6.46 / 167,125$ & 5.8 & 0.024 \\
\hline \multirow[t]{2}{*}{$22(-\mathrm{C} /+\mathrm{DM} 1+\mathrm{I})$} & Etoposide-induced protein 2.4 homolog & EI24_RAT & 94 & $5.21 / 20,121$ & $9.75 / 38,893$ & 4.71 & 0.016 \\
\hline & F-box/SPRY domain-containing protein 1 & FBSP1_RAT & 74 & & $8.41 / 25,759$ & 10.43 & \\
\hline $23(-\mathrm{C} /+\mathrm{DM} 1+\mathrm{I})$ & Fuctinin-2 & GALA_RAT & 143 & $5.38 / 17,721$ & $4.30 / 2,489$ & 54.55 & 0.014 \\
\hline $24(+C /-D M 1+I)$ & Serum albumin & ALBU_RAT & 124 & $6.24 / 51,484$ & $6.09 / 68,731$ & 4.44 & 0.003 \\
\hline $25(-\mathrm{C} /+\mathrm{DM} 1+\mathrm{I})$ & Alpha-1-antiproteinase & A1AT_RAT & 94 & $5.98 / 31,395$ & $5.70 / 46,136$ & 3.67 & 0.016 \\
\hline $26(-\mathrm{DM} 1 /+\mathrm{DM} 1+\mathrm{I})$ & Serine protease inhibitor A3L & SPA3L_RAT & 523 & $4.72 / 56,371$ & $5.48 / 46,277$ & 5.81 & 0.013 \\
\hline \multirow[t]{2}{*}{27 (+DM1/-DM1 + I) } & Transmembrane protein 11 , mitochondrial & TMM11_RAT & 124 & $5.21 / 52,609$ & $6.98 / 21,342$ & 3.68 & \\
\hline & 2'-deoxynucleoside 5'-phosphate $N$-hydrolase 1 & DNPH1_RAT & 102 & & $4.95 / 17,781$ & 9.82 & \\
\hline 28 (+DM1/-DM1 +I) & Probable N-acetyltransferase CML5 & CMLO5_RAT & 108 & $5.22 / 48.304$ & $8.99 / 25.167$ & 15.11 & 0.016 \\
\hline \multirow[t]{2}{*}{29 (+DM1/-DM1 + I) } & Vitamin D-binding protein & VTDB_RAT & 535 & $5.49 / 51.247$ & $5.65 / 53,544$ & 2.94 & 0.046 \\
\hline & Biliverdin reductase $\mathrm{A}$ & BIEA_RAT & 135 & & 33,566 & 13.56 & \\
\hline \multirow[t]{2}{*}{$30(-\mathrm{DM} 1 /+\mathrm{DM} 1+\mathrm{I})$} & Etoposide-induced protein 2.4 homolog & EI24_RAT & 94 & $6.24 / 51.484$ & $9.75 / 38,893$ & 4.71 & 0.011 \\
\hline & F-box/SPRY domain-containing protein 1 & FBSP1_RAT & 74 & & $8.41 / 25,759$ & 10.43 & \\
\hline $31(-\mathrm{DM} 1 /+\mathrm{DM} 1+\mathrm{I})$ & Alpha-1-macroglobulin & A1M_RAT & 81 & $5.99 / 32,532$ & $6.46 / 167,125$ & 0.6 & 0.003 \\
\hline $32(-\mathrm{DM} 1 /+\mathrm{DM} 1+\mathrm{I})$ & Haptoglobin & HPT_RAT & 281 & $5.18 / 31,546$ & $6.10 / 38,563$ & 13.26 & 0.001 \\
\hline $33(-\mathrm{DM} 1 /+\mathrm{DM} 1+\mathrm{I})$ & Haptoglobin & HPT_RAT & 67 & $5.18 / 31,546$ & $6.10 / 38,563$ & 3.46 & 0.015 \\
\hline $34(-\mathrm{DM} 1 /+\mathrm{DM} 1+\mathrm{I})$ & C-reactive protein & CRP_RAT & 76 & $4.41 / 26,661$ & $4.89 / 25,468$ & 5.22 & 0.038 \\
\hline $35(-\mathrm{DM} 1 /+\mathrm{DM} 1+\mathrm{I})$ & Not identified & & & $5.11 / 24,969$ & & & 0.024 \\
\hline $36(-\mathrm{DM} 1 /+\mathrm{DM} 1+\mathrm{I})$ & Serum amyloid P-component & SAMP_RAT & 124 & $4.92 / 23,098$ & $5.50 / 26,176$ & 16.23 & 0.047 \\
\hline $37(-\mathrm{DM} 1 /+\mathrm{DM} 1+\mathrm{I})$ & Not identified & & & $5.41 / 18,385$ & & & 0.013 \\
\hline \multirow{2}{*}{38 (-DM1/+DM1+I) } & Src kinase-associated phosphoprotein 1 & SKAP1_RAT & 39 & $5.64 / 16,826$ & $4.35 / 40,903$ & 4.8 & 0.045 \\
\hline & Synaptogyrin-2 & SNG2_RAT & 28 & & $4.61 / 24,711$ & 8.04 & \\
\hline 39 (+DM1/-DM1 +I) & Ig lambda-2 chain $C$ region & LAC2_RAT & 759 & $5.70 / 20,029$ & $5.76 / 11,318$ & 14.42 & 0.041 \\
\hline $40(-\mathrm{DM} 1 /+\mathrm{DM} 1+\mathrm{I})$ & Apolipoprotein A-I & APOA1_RAT & 64 & $5.99 / 16,766$ & $5.52 / 30,062$ & 3.47 & 0.049 \\
\hline 41 (+DM1/-DM1 +I) & Ig kappa chain $C$ region, $A$ allele & KACA_RAT & 363 & $6.07 / 19,496$ & $4.99 / 11,732$ & 28.3 & 0.014 \\
\hline \multirow[t]{2}{*}{$42(+\mathrm{DM} 1 /-\mathrm{DM} 1+\mathrm{I})$} & cAMP-regulated phosphoprotein 19 & ARP19_RAT & 88 & $6.22 / 18,449$ & $9.07 / 12,293$ & 38.39 & 0.011 \\
\hline & Proline-rich nuclear receptor coactivator 2 & PNRC2_RAT & 87 & & $10.19 / 14.881$ & 6.72 & \\
\hline 43 (+DM1/-DM1 +I) & Not identified & & & $6.99 / 19.839$ & & & 0.014 \\
\hline $44(-\mathrm{DM} 1 /+\mathrm{DM} 1+\mathrm{I})$ & Gamma-glutamylaminecyclotransferase & GGACT_RAT & 48 & $5.78 / 73,265$ & $6.03 / 16,925$ & 16.78 & 0.013 \\
\hline 45 (+DM1/-DM1 +I) & Alpha-1-antiproteinase & A1AT_RAT & 2143 & $5.78 / 49,014$ & $5.70 / 46,136$ & 14.11 & 0.001 \\
\hline
\end{tabular}




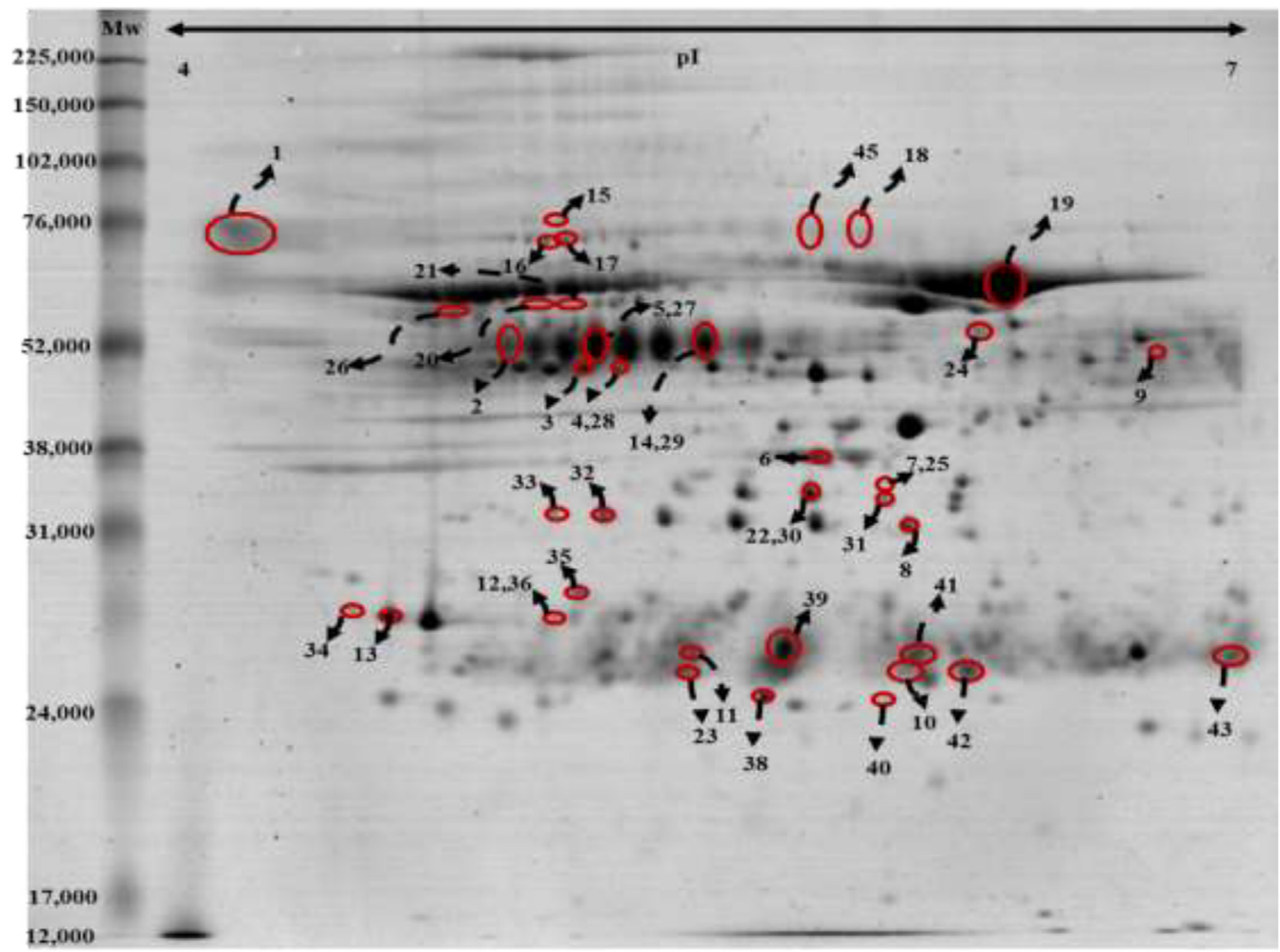

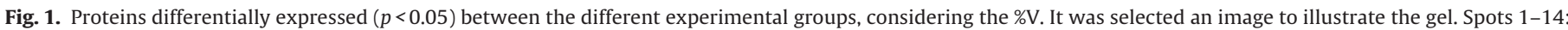


between DM1 and DM1 + I.

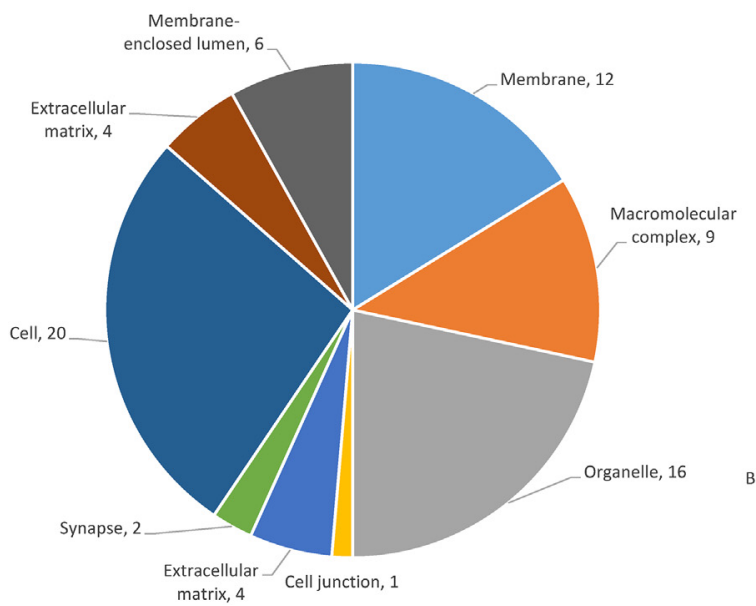

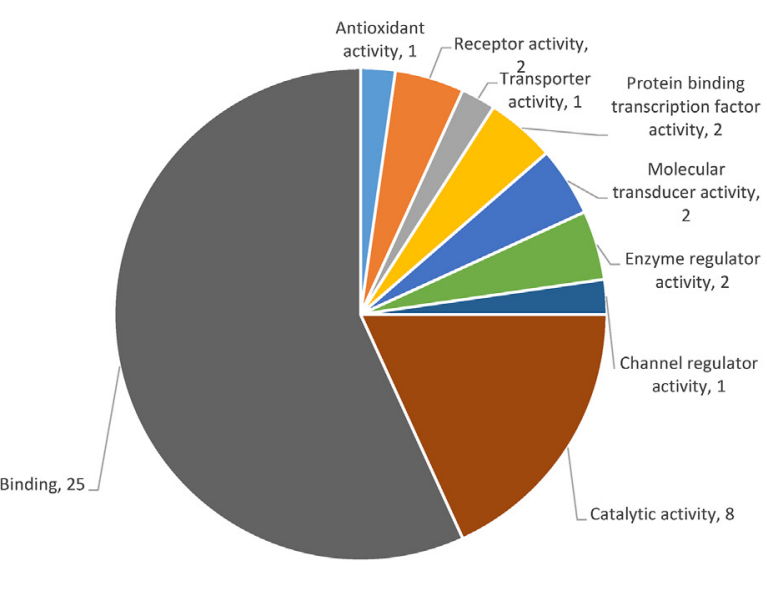

Fig. 2. Classification of sequences of proteins differentially expressed $(p<0.05)$. A. Cellular component. B. Molecular function.

\subsection{Electrophoretic runs}

The images were compared between pairs of gels by means of the matching process using ImageMaster Platinum version 7.0, which identifies the spots that are equivalent between pairs. The result of the image processing procedure yielded a correlation between the pairs of gels presented. Image processing of the electrophoretic runs disclosed, for example, average correlations between gels of $78 \%, 85 \%$, and $85 \%$ for C, DM1, and DM1 + I groups, respectively; this simplified mode means that the protein spots were present in two replications of these gels. This indicates good repeatability and reproducibility of repetitions performed on the same gels. In the study of gel images, correlations between protein spots of different experimental groups were estimated and compared with the $\% \mathrm{~V}$, which enabled us to evaluate a possible correlation between protein expression and the set of protein spots analyzed. Since we seek to understand the influence of protein expression in DM1, this strategy can provide information that allows us to discuss and understand them. The correlation between protein spots on gels C and DM1 ( $r>0.78), C$ and DM1 $+\mathrm{I}(\mathrm{r}>0.87)$, 
and gels DM1 and DM1 + I ( $r>0.67)$ was determined, considering the $\% \mathrm{~V}$. Correlation analysis allowed us to observe that the proteomic profiles of groups C and DM1 + I were closer to each other than those of groups $C$ and DM1. On the basis of this information, it can be inferred that the expression of plasma proteins in group $C$ is most similar to that of group DM1 $+\mathrm{I}$.

It was generally observed that the gels had a homogeneous distribution of protein spots according to their respective pIs and molecular masses in the different experimental groups. We also observed that most of the protein spots that make up the sample proteomic map in rat plasma were found to be distributed mainly in the molecular mass range of $31-76 \mathrm{kDa}$, more frequently in the range $5-6 \mathrm{pI}$.

\subsection{Differences in protein expression and quantitative analysis of $\mathrm{Cu}, \mathrm{Mg}$, Se, and $\mathrm{Zn}$}

A comparison between C and DM1 showed 149 coincident spots and 14 spots with differential expression, while C and DM1+I showed 175 coincident spots and 11 spots with differential expression, and DM1 and DM1 + I showed 143 coincident spots and 20 spots with differential expression, according to the analysis performed by ImageMaster Platinum version 7.0.

In Fig. 1 and Table 2, data regarding the characterization obtained in the analysis of proteins identified by ESI-MS/MS are shown. Of the 45 spots analyzed by ESI-MS/MS, three were not identified as proteins, which may be related to a fault in the tryptic digestion step - or even the low protein concentration - not generating peptides that could be sequenced; 35 different proteins were identified among the 45 protein spots analyzed.

Of these 35 proteins, their associated sequences were compared with those of cellular component- and molecular function-related sequences described in Fig. $2 A$ and $B$. These sequences were most associated with the cellular components cell (103), extracellular regions (19), and organelles (16), and with the molecular functions of binding (25) and catalytic activity (8).

The following concentrations were determined in feed analysis: Se: <LOQ Cu: $2.36 \mu \mathrm{g} \mathrm{L}^{-1}$, Mg: $28.90 \mu \mathrm{g} \mathrm{L}^{-1}$, and $\mathrm{Zn}: 51.40 \mu \mathrm{g} \mathrm{L}^{-1}$, with major sources of $\mathrm{Mg}$ and $\mathrm{Zn}$. In total plasma, the concentrations were determined as Cu: $84.06 \mu \mathrm{g} \mathrm{L}^{-1}, \mathrm{Mg}: 2141.10 \mu \mathrm{g} \mathrm{L}^{-1}$, Se: $157.33 \mu \mathrm{g} \mathrm{L}^{-} 1$, and $\mathrm{Zn}: 2340.73 \mu \mathrm{g} \mathrm{L}^{-1}$ in C; $\mathrm{Cu}: 59.40 \mu \mathrm{g} \mathrm{L}^{-1}$, $\mathrm{Mg}$ : 2122.20 $\mu \mathrm{g} \mathrm{L}^{-1}$, Se: $250.48 \mu \mathrm{g} \mathrm{L}^{-1}$, and Zn: $2377.02 \mu \mathrm{g} \mathrm{L}^{-1}$ in DM1; and $\mathrm{Cu}: 82.74 \mu \mathrm{gL}^{-1}$, Mg: $2115.90 \mu \mathrm{gL}^{-1}$, Se: $146.98 \mu \mathrm{g} \mathrm{L}^{-1}$, and $\mathrm{Zn}: 4129.65 \mu \mathrm{g} \mathrm{L}^{-1}$ in DM1 + I. High plasma Se was found in our study, as observed in other studies that associated high serum Se concentration with an increased prevalence of diabetes [24,25].

Table 3 shows the quantitative determination of $\mathrm{Cu}, \mathrm{Mg}$, Se, and $\mathrm{Zn}$ in the protein spots with different expression between the experimental groups.

In spot $1(-C /+D M 1)$, there were two proteins: histidine-rich glycoprotein and plasma protease $\mathrm{C} 1$ inhibitor. Histidine-rich glycoprotein is involved in the transport of glucose, and negatively regulates fibrinogens and signaling of vascular endothelial growth factor [26]. Plasma protease C1 inhibitor is involved in the innate immune response, the regulation of proteolysis, and the negative regulation of complement activation. With regard to lectin and endopeptidase activity, these were upregulated in DM1. In this study, Mg and Se were found in the plasma of DM1 animals. Histidine-rich glycoproteins bind with divalent metals [27], and the literature reports binding with $\mathrm{Cu}, \mathrm{Zn}, \mathrm{Ni}$, and mercury $(\mathrm{Hg})$, for example; this could explain why we found $\mathrm{Mg}$ and Se.

Small kinetochore-associated protein $(+C /-D M 1)$ is related to cell division as an essential component of the mitotic spindle that is required for chromosome segregation and anaphase progression; this promotes the metaphase to anaphase transition and is necessary for the alignment of chromosomes and the normal segregation of sister chromatids [28]. There are no reports in the literature that this protein has a specific metal-binding property, but in our work, we found $\mathrm{Cu}, \mathrm{Se}$, and $\mathrm{Zn}$ in $\mathrm{C}$ and $\mathrm{Mg}$ and Se in DM1. The presence of a cysteine in the amino acid composition could explain the binding of these metals.

Alpha-1-antiproteinase was found in spots 3, 4, 7 (+C/-DM1), 25 $(-\mathrm{C} /+\mathrm{DM} 1+\mathrm{I})$, and 45 (+DM1/-DM1+I). Alpha-1-antiproteinase is an inhibitor of serine proteases; its primary target is elastase, but it also has a moderate affinity for plasmin and thrombin, exerts responses to hypoxia, triglycerides, and lipopolysaccharides, stimulates estradiol, cytosine, and peptide hormones, downregulates endopeptidase activity, and is involved in the regulation of proteolysis [29]. Alpha-1-antiproteinase protects the connective tissue from inflammatory enzymes and helps to prevent blood clotting, which could be related to why this protein was more highly expressed in group $C$ than in group DM1. Levels of serum acutephase protein groups were shown to correlate positively with blood pressure in humans [30]; this is one of the most abundant proteins in the urine of patients with proteinuria, and has been suggested as a marker of glomerulopathy. The somewhat increased expression of this protein in DM1 compared with DM1 + I may be due to some secondary complication of the disease. In $\mathrm{C}$, it was shown to bind to $\mathrm{Cu}$, Se, and $\mathrm{Zn}$, while in DM1 + I, it bound to $\mathrm{Mg}$ and Se. We did not find any reports in the literature, which may suggest that this is a newly discovered interaction.

In spots $5(-\mathrm{C} /+\mathrm{DM} 1)$ and $27(+\mathrm{DM} 1 /-\mathrm{DM} 1+\mathrm{I})$, we identified protein $2^{\prime}$-deoxynucleoside $5^{\prime}$-phosphate $N$-hydrolase 1 and transmembrane protein 11 . The protein $2^{\prime}$-deoxynucleoside $5^{\prime}$ phosphate $N$-hydrolase 1 is involved in metabolic processes for the positive regulation of nucleotide synthesis, cell proliferation, and cell growth; this enzyme catalyzes the cleavage of $N$-glycosidic deoxyribonucleoside-5'-monophosphate to produce deoxyribose 5 -phosphate and a purine or pyrimidine base, and can be upregulated in response to c-myc and by partial hepatectomy [31]. This protein presents no reports related to diabetes, but it is known to be mainly upregulated in response to c-myc; this gene encodes proteins that regulate gene transcription and thus may influence the cell response [32]. In vitro studies of mesangial cells by Wolf et al. [33] showed that c-myc is expressed when cells are exposed to high glucose concentrations, which may explain to some extent why this protein is upregulated in diabetic animals. Mitochondrial transmembrane protein 11 is related to negative regulation of cell growth by gluconeogenesis and glycolysis [34], which explains its upregulation in animals from group DM1. There are no reports in the literature on metal binding to this protein; in our study, there was binding of $\mathrm{Cu}$ and $\mathrm{Se}$ in $\mathrm{C}$, and $\mathrm{Cu}, \mathrm{Mg}$, and $\mathrm{Zn}$ in $\mathrm{DM} 1+\mathrm{I}$.

Haptoglobin (spot 8: $-\mathrm{C} /+\mathrm{DM} 1$; spot 32 and 33: -DM1/+DM1+I) captures and combines with free plasma hemoglobin to allow hepatic recycling of heme iron to prevent kidney damage, acts as an antioxidant, and plays a modulatory role in various aspects of the acute-phase response [35]. This protein was shown to bind with $\mathrm{Cu}$ (DM1 and C), Se (C, DM1, and DM1 + I), Mg (DM1), and Zn (DM1 + I).

Fibrinogen beta chain $(-\mathrm{C} /+\mathrm{DM} 1)$ acts in translational signaling protein polymerization, tissue regeneration, and cellular responses to the stimulation of leptin and interleukin-1, because they are associated with the inflammatory response and the risk of secondary complications, such as the risk of coronary heart disease observed in DM1 [36]. Also in spot $9(-\mathrm{C} /+\mathrm{DM} 1)$ we identified Ig gamma- 1 chain $C$ region, taste receptor type 2 member 114 , and the presence of Se in $\mathrm{C}$.

Galanin peptides $(-C /+D M 1)$ are involved in the regulation of inflammatory immune responses, which are related to carbohydrate metabolism and the regulation of glucocorticoid metabolism, and inhibit glucose-induced insulin release [37]. Protein phosphatase 1 regulatory subunit 11 (C/DM1) negatively regulates 
Table 3

Determination of $\mathrm{Cu}, \mathrm{Mg}$, Se and $\mathrm{Zn}$ in the different experimental groups.

\begin{tabular}{|c|c|c|c|c|c|c|c|c|c|c|c|c|c|c|}
\hline \multicolumn{5}{|l|}{ C } & \multicolumn{5}{|l|}{ DM1 } & \multicolumn{5}{|l|}{ DM1 + I } \\
\hline Spot Id & $\begin{array}{l}\mathrm{Cu} \\
\mu \mathrm{gL}^{-1}\end{array}$ & $\begin{array}{l}\mathrm{Mg} \\
\mu \mathrm{gL}^{-1}\end{array}$ & $\begin{array}{l}\mathrm{Se} \\
\mu \mathrm{gL}^{-1}\end{array}$ & $\begin{array}{l}\mathrm{Zn} \\
\mu \mathrm{gL}^{-1}\end{array}$ & Spot Id & $\begin{array}{l}\mathrm{Cu} \\
\mu \mathrm{gL}^{-1}\end{array}$ & $\begin{array}{l}\mathrm{Mg} \\
\mu \mathrm{g} \mathrm{L}^{-1}\end{array}$ & $\begin{array}{l}\mathrm{Se} \\
\mu \mathrm{gL}^{-1}\end{array}$ & $\begin{array}{l}\mathrm{Zn} \\
\mu \mathrm{g} \mathrm{L}^{-1}\end{array}$ & Spot Id & $\begin{array}{l}\mathrm{Cu} \\
\mu \mathrm{gL}^{-1}\end{array}$ & $\begin{array}{l}\mathrm{Mg} \\
\mu \mathrm{g} \mathrm{L}^{-1}\end{array}$ & $\begin{array}{l}\mathrm{Se} \\
\mu \mathrm{gL}^{-1}\end{array}$ & $\begin{array}{l}\mathrm{Zn} \\
\mu \mathrm{gL}^{-1}\end{array}$ \\
\hline 1 & $<\mathrm{LOQ}$ & $<\mathrm{LOQ}$ & $<\mathrm{LOQ}$ & $<\mathrm{LOQ}$ & 1 & $<\mathrm{LOQ}$ & $<\mathrm{LOQ}$ & $<\mathrm{LOQ}$ & $<\mathrm{LOQ}$ & 1 & $<\mathrm{LOQ}$ & $97 \pm 2.91$ & $41 \pm 1.23$ & $<\mathrm{LOQ}$ \\
\hline 2 & $23 \pm 0.69$ & $<\mathrm{LOQ}$ & $0.42 \pm 0.01$ & $94 \pm 2.82$ & 2 & $<\mathrm{LOQ}$ & $<\mathrm{LOQ}$ & $<\mathrm{LOQ}$ & $<\mathrm{LOQ}$ & 2 & $<\mathrm{LOQ}$ & $152 \pm 4.56$ & $0.67 \pm 0.02$ & $<\mathrm{LOQ}$ \\
\hline 3 & $17 \pm 0.51$ & $<\mathrm{LOQ}$ & $23 \pm 0.69$ & $12 \pm 0.36$ & 3 & $<\mathrm{LOQ}$ & $<$ LOQ & $<\mathrm{LOQ}$ & $<\mathrm{LOQ}$ & 3 & $<\mathrm{LOQ}$ & $260 \pm 7.8$ & $11 \pm 0.33$ & $<\mathrm{LOQ}$ \\
\hline 4 & $22 \pm 0.66$ & $<\mathrm{LOQ}$ & $0.96 \pm 0.02$ & $<\mathrm{LOQ}$ & 4 & $<\mathrm{LOQ}$ & $<\mathrm{LOQ}$ & $<\mathrm{LOQ}$ & $<\mathrm{LOQ}$ & 4 & $<\mathrm{LOQ}$ & $237 \pm 7.11$ & $17 \pm 0.51$ & $<\mathrm{LOQ}$ \\
\hline 5 & $0.74 \pm 0.02$ & $<\mathrm{LOQ}$ & $13 \pm 0.39$ & $<\mathrm{LOQ}$ & 6 & $<\mathrm{LOQ}$ & $<\mathrm{LOQ}$ & $<\mathrm{LOQ}$ & $<\mathrm{LOQ}$ & 5 & $<\mathrm{LOQ}$ & $82 \pm 2.46$ & $0.56 \pm 0.02$ & $<\mathrm{LOQ}$ \\
\hline 6 & $<$ LOQ & $<\mathrm{LOQ}$ & $<\mathrm{LOQ}$ & $<\mathrm{LOQ}$ & 5 & $<\mathrm{LOQ}$ & $<\mathrm{LOQ}$ & $<\mathrm{LOQ}$ & $<\mathrm{LOQ}$ & 6 & $<\mathrm{LOQ}$ & $127 \pm 3.81$ & $41 \pm 1.23$ & $569 \pm 17.07$ \\
\hline 7 & $<\mathrm{LOQ}$ & $<\mathrm{LOQ}$ & $0.65 \pm 0.02$ & $<\mathrm{LOQ}$ & 7 & $63 \pm 1.89$ & $<\mathrm{LOQ}$ & $<\mathrm{LOQ}$ & $<\mathrm{LOQ}$ & 7 & $<\mathrm{LOQ}$ & $245 \pm 7.35$ & $15 \pm 0.45$ & $524 \pm 15.72$ \\
\hline 8 & $<\mathrm{LOQ}$ & $<\mathrm{LOQ}$ & $20 \pm 0.6$ & $<\mathrm{LOQ}$ & 8 & $46 \pm 1.38$ & $<\mathrm{LOQ}$ & $56 \pm 1.68$ & $<\mathrm{LOQ}$ & 8 & $<\mathrm{LOQ}$ & $225 \pm 6.75$ & $0.79 \pm 0.02$ & $578 \pm 17.34$ \\
\hline 9 & $<\mathrm{LOQ}$ & $<\mathrm{LOQ}$ & $16 \pm 0.48$ & $<\mathrm{LOQ}$ & 9 & $<\mathrm{LOQ}$ & $<\mathrm{LOQ}$ & $<\mathrm{LOQ}$ & $<\mathrm{LOQ}$ & 9 & $<\mathrm{LOQ}$ & $<$ LOQ & $<\mathrm{LOQ}$ & $<\mathrm{LOQ}$ \\
\hline 10 & $<\mathrm{LOQ}$ & $<\mathrm{LOQ}$ & $<\mathrm{LOQ}$ & $<\mathrm{LOQ}$ & 10 & $31 \pm 0.93$ & $<\mathrm{LOQ}$ & $10 \pm 0.3$ & $<\mathrm{LOQ}$ & 10 & $<\mathrm{LOQ}$ & $<\mathrm{LOQ}$ & $<\mathrm{LOQ}$ & $14 \pm 0.42$ \\
\hline 11 & $0.97 \pm 0.03$ & $<\mathrm{LOQ}$ & $17 \pm 0.51$ & $<\mathrm{LOQ}$ & 11 & $<\mathrm{LOQ}$ & $<\mathrm{LOQ}$ & $<\mathrm{LOQ}$ & $<\mathrm{LOQ}$ & 11 & $<\mathrm{LOQ}$ & $67 \pm$ & $<\mathrm{LOQ}$ & $<\mathrm{LOQ}$ \\
\hline 12 & $<\mathrm{LOQ}$ & $<\mathrm{LOQ}$ & $<\mathrm{LOQ}$ & $<\mathrm{LOQ}$ & 12 & $<\mathrm{LOQ}$ & $<\mathrm{LOQ}$ & $<\mathrm{LOQ}$ & $<\mathrm{LOQ}$ & 12 & $<\mathrm{LOQ}$ & $<\mathrm{LOQ}$ & $<\mathrm{LOQ}$ & $<\mathrm{LOQ}$ \\
\hline 13 & $32 \pm 0.96$ & $<\mathrm{LOQ}$ & $22 \pm 0.66$ & $<\mathrm{LOQ}$ & 13 & $0.67 \pm 0.02$ & $<\mathrm{LOQ}$ & $54 \pm 1.62$ & $<\mathrm{LOQ}$ & 13 & $<\mathrm{LOQ}$ & $212 \pm$ & $11 \pm$ & $674 \pm$ \\
\hline 14 & $<\mathrm{LOQ}$ & $<\mathrm{LOQ}$ & $<\mathrm{LOQ}$ & $<\mathrm{LOQ}$ & 14 & $<\mathrm{LOQ}$ & $<\mathrm{LOQ}$ & $<\mathrm{LOQ}$ & $<\mathrm{LOQ}$ & 14 & $<\mathrm{LOQ}$ & $<\mathrm{LOQ}$ & $<\mathrm{LOQ}$ & $<\mathrm{LOQ}$ \\
\hline 15 & $0.87 \pm 0.03$ & $<\mathrm{LOQ}$ & $0.90 \pm 0.03$ & $<\mathrm{LOQ}$ & 15 & $<\mathrm{LOQ}$ & $<\mathrm{LOQ}$ & $0.65 \pm 0.02$ & $105 \pm 3.15$ & 15 & $<\mathrm{LOQ}$ & $220 \pm$ & $0.90 \pm$ & $<\mathrm{LOQ}$ \\
\hline 16 & $0.37 \pm 0.01$ & $<\mathrm{LOQ}$ & $12 \pm 0.36$ & $<\mathrm{LOQ}$ & 16 & $27 \pm 0.81$ & $<\mathrm{LOQ}$ & $0.65 \pm 0.02$ & $<\mathrm{LOQ}$ & 16 & $<\mathrm{LOQ}$ & $102 \pm 3.06$ & $36 \pm 1.08$ & $<\mathrm{LOQ}$ \\
\hline 17 & $0.95 \pm 0.03$ & $<\mathrm{LOQ}$ & $0.87 \pm 0.03$ & $<\mathrm{LOQ}$ & 17 & $<\mathrm{LOQ}$ & $<$ LOQ & $<$ LOQ & $<\mathrm{LOQ}$ & 17 & $<\mathrm{LOQ}$ & $<$ LOQ & $<\mathrm{LOQ}$ & $<\mathrm{LOQ}$ \\
\hline 18 & $<\mathrm{LOQ}$ & $<\mathrm{LOQ}$ & $0.20 \pm 0.006$ & $<\mathrm{LOQ}$ & 18 & $<\mathrm{LOQ}$ & $<\mathrm{LOQ}$ & $<\mathrm{LOQ}$ & $95 \pm 2.85$ & 18 & $<\mathrm{LOQ}$ & $0.5 \pm 0.01$ & $33 \pm 0.99$ & $723 \pm 21.69$ \\
\hline 19 & $<\mathrm{LOQ}$ & $<\mathrm{LOQ}$ & $<\mathrm{LOQ}$ & $<\mathrm{LOQ}$ & 19 & $<\mathrm{LOQ}$ & $<\mathrm{LOQ}$ & $<\mathrm{LOQ}$ & $<\mathrm{LOQ}$ & 19 & $<\mathrm{LOQ}$ & $<\mathrm{LOQ}$ & $<\mathrm{LOQ}$ & $<\mathrm{LOQ}$ \\
\hline 20 & $0.46 \pm 0.01$ & $<\mathrm{LOQ}$ & $0.96 \pm 0.03$ & $<\mathrm{LOQ}$ & 20 & $<\mathrm{LOQ}$ & $<\mathrm{LOQ}$ & $<\mathrm{LOQ}$ & $<\mathrm{LOQ}$ & 20 & $<\mathrm{LOQ}$ & $<\mathrm{LOQ}$ & $<\mathrm{LOQ}$ & $<\mathrm{LOQ}$ \\
\hline 21 & $<\mathrm{LOQ}$ & $<\mathrm{LOQ}$ & $<\mathrm{LOQ}$ & $<\mathrm{LOQ}$ & 21 & $<\mathrm{LOQ}$ & $<\mathrm{LOQ}$ & $<\mathrm{LOQ}$ & $<\mathrm{LOQ}$ & 21 & $<\mathrm{LOQ}$ & $<\mathrm{LOQ}$ & $<\mathrm{LOQ}$ & $<\mathrm{LOQ}$ \\
\hline 22 & $<\mathrm{LOQ}$ & $<\mathrm{LOQ}$ & $<\mathrm{LOQ}$ & $<\mathrm{LOQ}$ & 22 & $41 \pm 1.23$ & $185 \pm 5.55$ & $<\mathrm{LOQ}$ & $<\mathrm{LOQ}$ & 22 & $<\mathrm{LOQ}$ & $397 \pm 11.91$ & $0.11 \pm 0.003$ & $0.07 \pm 0.002$ \\
\hline 23 & $<\mathrm{LOQ}$ & $<\mathrm{LOQ}$ & $<\mathrm{LOQ}$ & $<\mathrm{LOQ}$ & 23 & $<\mathrm{LOQ}$ & $<\mathrm{LOQ}$ & $<\mathrm{LOQ}$ & $<\mathrm{LOQ}$ & 23 & $<\mathrm{LOQ}$ & $<\mathrm{LOQ}$ & $<\mathrm{LOQ}$ & $<\mathrm{LOQ}$ \\
\hline 24 & $<\mathrm{LOQ}$ & $<\mathrm{LOQ}$ & $13 \pm 0.39$ & $<\mathrm{LOQ}$ & 24 & $<\mathrm{LOQ}$ & $<\mathrm{LOQ}$ & $<\mathrm{LOQ}$ & $<\mathrm{LOQ}$ & 24 & $<\mathrm{LOQ}$ & $412 \pm 12.63$ & $11 \pm 0.33$ & $<\mathrm{LOQ}$ \\
\hline 25 & $<\mathrm{LOQ}$ & $<\mathrm{LOQ}$ & $<\mathrm{LOQ}$ & $<\mathrm{LOQ}$ & 25 & $<\mathrm{LOQ}$ & $<\mathrm{LOQ}$ & $1 \pm 0.03$ & $107 \pm 3.21$ & 25 & $<\mathrm{LOQ}$ & $<\mathrm{LOQ}$ & $<\mathrm{LOQ}$ & $<\mathrm{LOQ}$ \\
\hline 26 & $<\mathrm{LOQ}$ & $<\mathrm{LOQ}$ & $<\mathrm{LOQ}$ & $<\mathrm{LOQ}$ & 26 & $<$ LOQ & $<\mathrm{LOQ}$ & $<\mathrm{LOQ}$ & $<\mathrm{LOQ}$ & 26 & $<\mathrm{LOQ}$ & $182 \pm 5.46$ & $34 \pm 1.02$ & $<\mathrm{LOQ}$ \\
\hline 27 & $0.20 \pm 0.006$ & $<\mathrm{LOQ}$ & $0.99 \pm 0.03$ & $<\mathrm{LOQ}$ & 27 & $34 \pm 1.02$ & $70 \pm 2.1$ & $<\mathrm{LOQ}$ & $<\mathrm{LOQ}$ & 27 & $<\mathrm{LOQ}$ & $<\mathrm{LOQ}$ & $<\mathrm{LOQ}$ & $<\mathrm{LOQ}$ \\
\hline 28 & $<\mathrm{LOQ}$ & $<\mathrm{LOQ}$ & $<\mathrm{LOQ}$ & $<\mathrm{LOQ}$ & 28 & $<\mathrm{LOQ}$ & $32 \pm 0.96$ & $<\mathrm{LOQ}$ & $<\mathrm{LOQ}$ & 28 & $<\mathrm{LOQ}$ & $<\mathrm{LOQ}$ & $<\mathrm{LOQ}$ & $<\mathrm{LOQ}$ \\
\hline 29 & $0.73 \pm 0.02$ & $<\mathrm{LOQ}$ & $32 \pm 0.96$ & $<\mathrm{LOQ}$ & 29 & $<\mathrm{LOQ}$ & $<\mathrm{LOQ}$ & $<\mathrm{LOQ}$ & $<\mathrm{LOQ}$ & 29 & $<\mathrm{LOQ}$ & $<\mathrm{LOQ}$ & $<\mathrm{LOQ}$ & $<\mathrm{LOQ}$ \\
\hline 30 & $<\mathrm{LOQ}$ & $<\mathrm{LOQ}$ & $20 \pm 0.6$ & 23 & 30 & $125 \pm 3.75$ & $<\mathrm{LOQ}$ & $65 \pm 1.95$ & $<\mathrm{LOQ}$ & 30 & $<\mathrm{LOQ}$ & $<\mathrm{LOQ}$ & $<\mathrm{LOQ}$ & $<\mathrm{LOQ}$ \\
\hline 31 & $<\mathrm{LOQ}$ & $<\mathrm{LOQ}$ & $<\mathrm{LOQ}$ & $<\mathrm{LOQ}$ & 31 & $<\mathrm{LOQ}$ & $<\mathrm{LOQ}$ & $<\mathrm{LOQ}$ & $<\mathrm{LOQ}$ & 31 & $<\mathrm{LOQ}$ & $<\mathrm{LOQ}$ & $<\mathrm{LOQ}$ & $<\mathrm{LOQ}$ \\
\hline 32 & $37 \pm 1.11$ & $<\mathrm{LOQ}$ & $15 \pm 0.45$ & $<\mathrm{LOQ}$ & 32 & $0.58 \pm 0.02$ & $<\mathrm{LOQ}$ & $42 \pm 1.26$ & $<\mathrm{LOQ}$ & 32 & $<\mathrm{LOQ}$ & $112 \pm 3.36$ & $28 \pm 0.84$ & $58 \pm 1.74$ \\
\hline 33 & $<\mathrm{LOQ}$ & $<\mathrm{LOQ}$ & $29 \pm 0.87$ & $<\mathrm{LOQ}$ & 33 & $0.85 \pm 0.02$ & $<\mathrm{LOQ}$ & $46 \pm 1.38$ & $<\mathrm{LOQ}$ & 33 & $<\mathrm{LOQ}$ & $275 \pm 8.25$ & $34 \pm 1.02$ & $546 \pm 16.38$ \\
\hline 34 & $<\mathrm{LOQ}$ & $<\mathrm{LOQ}$ & $<\mathrm{LOQ}$ & $<\mathrm{LOQ}$ & 34 & $<\mathrm{LOQ}$ & $<\mathrm{LOQ}$ & $<\mathrm{LOQ}$ & $<\mathrm{LOQ}$ & 34 & $<\mathrm{LOQ}$ & $<$ LOQ & $<\mathrm{LOQ}$ & $<\mathrm{LOQ}$ \\
\hline 35 & $<\mathrm{LOQ}$ & $<\mathrm{LOQ}$ & $<\mathrm{LOQ}$ & $<\mathrm{LOQ}$ & 35 & $0.087 \pm 0.003$ & $<\mathrm{LOQ}$ & $59 \pm 1.77$ & $<\mathrm{LOQ}$ & 35 & $<\mathrm{LOQ}$ & $<\mathrm{LOQ}$ & $<\mathrm{LOQ}$ & $<\mathrm{LOQ}$ \\
\hline 36 & $<\mathrm{LOQ}$ & $<\mathrm{LOQ}$ & $<\mathrm{LOQ}$ & $<\mathrm{LOQ}$ & 36 & $<\mathrm{LOQ}$ & $<\mathrm{LOQ}$ & $<$ LOQ & $<\mathrm{LOQ}$ & 36 & $<\mathrm{LOQ}$ & $<\mathrm{LOQ}$ & $<\mathrm{LOQ}$ & $<\mathrm{LOQ}$ \\
\hline 37 & $37 \pm 1.11$ & $<\mathrm{LOQ}$ & $10 \pm 0.3$ & $<\mathrm{LOQ}$ & 37 & $<\mathrm{LOQ}$ & $<\mathrm{LOQ}$ & $<\mathrm{LOQ}$ & $<\mathrm{LOQ}$ & 37 & $<\mathrm{LOQ}$ & $<\mathrm{LOQ}$ & $<\mathrm{LOQ}$ & $<\mathrm{LOQ}$ \\
\hline 38 & $<\mathrm{LOQ}$ & $<\mathrm{LOQ}$ & $0.87 \pm 0.03$ & $<\mathrm{LOQ}$ & 38 & $<\mathrm{LOQ}$ & $<\mathrm{LOQ}$ & $11 \pm 0.33$ & $<\mathrm{LOQ}$ & 38 & $<\mathrm{LOQ}$ & $<\mathrm{LOQ}$ & $11 \pm 0.33$ & $<\mathrm{LOQ}$ \\
\hline 39 & $<\mathrm{LOQ}$ & $<\mathrm{LOQ}$ & $<\mathrm{LOQ}$ & $<\mathrm{LOQ}$ & 39 & $24 \pm 0.72$ & $<\mathrm{LOQ}$ & $<\mathrm{LOQ}$ & $<\mathrm{LOQ}$ & 39 & $<\mathrm{LOQ}$ & $<\mathrm{LOQ}$ & $0.28 \pm 0.01$ & $<\mathrm{LOQ}$ \\
\hline 40 & $<\mathrm{LOQ}$ & $<\mathrm{LOQ}$ & $0.60 \pm 0.02$ & $<\mathrm{LOQ}$ & 40 & $20 \pm 0.6$ & $112 \pm 3.36$ & $<\mathrm{LOQ}$ & $<\mathrm{LOQ}$ & 40 & $<\mathrm{LOQ}$ & $<\mathrm{LOQ}$ & $0.78 \pm 0.02$ & $<\mathrm{LOQ}$ \\
\hline 41 & $<\mathrm{LOQ}$ & $<\mathrm{LOQ}$ & $22 \pm 0.66$ & $<\mathrm{LOQ}$ & 41 & $<\mathrm{LOQ}$ & $<\mathrm{LOQ}$ & $<\mathrm{LOQ}$ & $<\mathrm{LOQ}$ & 41 & $<\mathrm{LOQ}$ & $<\mathrm{LOQ}$ & $<\mathrm{LOQ}$ & $<\mathrm{LOQ}$ \\
\hline 42 & $12 \pm 0.36$ & $1 \pm 0.03$ & $16 \pm 0.48$ & $<\mathrm{LOQ}$ & 42 & $26 \pm 0.78$ & $<$ LOQ & $<\mathrm{LOQ}$ & $<\mathrm{LOQ}$ & 42 & $<\mathrm{LOQ}$ & $<\mathrm{LOQ}$ & $<\mathrm{LOQ}$ & $<\mathrm{LOQ}$ \\
\hline 43 & $<\mathrm{LOQ}$ & $<\mathrm{LOQ}$ & $<\mathrm{LOQ}$ & $<\mathrm{LOQ}$ & 43 & $<\mathrm{LOQ}$ & $<\mathrm{LOQ}$ & $<\mathrm{LOQ}$ & $<\mathrm{LOQ}$ & 43 & $<\mathrm{LOQ}$ & $<\mathrm{LOQ}$ & $<\mathrm{LOQ}$ & $<\mathrm{LOQ}$ \\
\hline 44 & $<\mathrm{LOQ}$ & $<\mathrm{LOQ}$ & $27 \pm 0.81$ & $<\mathrm{LOQ}$ & 44 & $0.20 \pm 0.006$ & $<\mathrm{LOQ}$ & $<\mathrm{LOQ}$ & $<\mathrm{LOQ}$ & 44 & $<\mathrm{LOQ}$ & $<\mathrm{LOQ}$ & $<\mathrm{LOQ}$ & $<\mathrm{LOQ}$ \\
\hline 45 & $<\mathrm{LOQ}$ & $<\mathrm{LOQ}$ & $<\mathrm{LOQ}$ & $<\mathrm{LOQ}$ & 45 & $<\mathrm{LOQ}$ & $<\mathrm{LOQ}$ & $1 \pm 0.03$ & $<\mathrm{LOQ}$ & 45 & $<\mathrm{LOQ}$ & $<\mathrm{LOQ}$ & $<\mathrm{LOQ}$ & $<\mathrm{LOQ}$ \\
\hline
\end{tabular}


catalytic activity [38]. In spot 10, Cu and Se were found in DM1, and $\mathrm{Zn}$ in DM1 $+\mathrm{I}$. There are no reports about these proteins binding to $\mathrm{Cu}$, Se, and $\mathrm{Zn}$.

Serum amyloid P component (spot 12: +C/-DM1; spot 36: -DM1/+DM1 + I) binds two calcium ions per subunit. A precursor of amyloid $\mathrm{P}$ component, which is found in the basal and associated with amyloid deposits in the membrane, it also acts as a complexforming protein [39], and in this case was downregulated in animals from group DM1. In our study, there was no presence of $\mathrm{Cu}, \mathrm{Mg}, \mathrm{Se}$, or $\mathrm{Zn}$ associated with this protein in spots 12 and 36.

Neutrophil cytosol factor 2(-C/+DM1) was upregulated in DM1; this may be because its function is related to response to glucose stimulus, catabolic processes involved in the NADP-dependent generation of superoxide anions, and cellular defense responses [40]. Neutrophil cytosol factor 2 showed the presence of $\mathrm{Cu}$ and $\mathrm{Se}$ in $\mathrm{C}$ and DM1, and Mg, Se, and Zn in DM1 + I.

Vitamin D-binding protein (spot 14: -C/+DM1; spot 29: +DM1/-DM1 + I) in plasma carries vitamin D sterols and prevents polymerization of actin monomers, connecting their present response to tumor necrosis factor, vitamin $\mathrm{D}$ metabolic processes, and cellular death factor [41]. This is related to cardiovascular diseases arising from diabetes, and this mechanism was found to be upregulated in DM1. Biliverdin reductase A (spot 14: $-C /+D M 1$; spot 29: +DM1/-DM1+I) is involved in metabolic processes of small molecules, heme, and catabolic processes in redox processes (with concomitant oxidation of the NADH or NADPH cofactor) [42]. A previous study has shown that biliverdin reductase suppresses insulin signaling and acts as a negative regulator of glucose uptake [42], in a way explaining its upregulation in DM1 animals; it also binds to the p85 regulatory subunit of PI3K/Akt [43], a mechanism that may also lead to an improvement in insulin sensitivity [44]. However, these animals may have increased the expression of this protein, trying to supply insulin or reset the mechanism responsible for insulin deficiency in the pathological state. In addition, there was no association with the presence of $\mathrm{Cu}, \mathrm{Mg}$, Se, or $\mathrm{Zn}$ in this spot.

Afamin (+C/-DM1) is a protein linked to vitamin E that can be carried in body fluids under conditions where the system does not contain sufficient lipoproteins. Afamin has already been reported to be an ovarian cancer marker [45], but its relationship to diabetes has not been previously reported. In this study, it was shown to be downregulated, which may have resulted in increased oxidative stress in diabetes due to the overproduction of reactive oxygen species (ROS) and decreased efficiency of antioxidant defenses. Moreover, the carrying capacity of vitamin E, as a non-enzymatic antioxidant system in diabetes, may be reduced due to a decreased ability to remove ROS, thus explaining the downregulation of afamin in DM1. The presence of Cu and Se in C, Se and Zn in DM1, and $\mathrm{Mg}$ and Se in DM1 + I was observed.

Alpha-1-macroglobulin (spot 21: $-\mathrm{C} /+\mathrm{DM} 1+\mathrm{I}$; spot 31 : $-\mathrm{DM} 1 /+\mathrm{DM} 1+\mathrm{I})$ is able to inhibit all four classes of proteases by a single mechanism. This protein has a length of peptide that contains specific cleavage sites for different proteases: proteinase cleaves a certain region, and a conformational change in the protein induces proteinase to retain the encapsulated enzyme, which remains active against low molecular weight substrates (activity against substrates of high molecular weight is very low) [46]. Then, one thioester bond in the cleavage region is hydrolyzed and mediates binding of the protein to a covalent proteinase, causing further downregulation of endopeptidase activity [46]. The DM1 + I group showed increased expression of this protein, which may be explained by insulin treatment in these animals having reduced the effects of endotoxin-induced shock, but also being able to modulate the immunological response in plasma, somewhat controlling the secondary complications of DM1. In addition, our study suggests that alpha-1-macroglobulin could play a local anti-inflammatory role [47]. The presence of $\mathrm{Cu}, \mathrm{Mg}$, Se, and Zn was not observed in these two spots (21 and 31).

C-reactive protein (-DM1/+DM1+I) is a metalloprotein (binds two calcium ions per subunit) that has several functions associated with host defense: it promotes agglutination, phagocytosis, and complement fixation through calcium-dependent binding to phosphorylcholine, can interact with DNA and histones and clean nuclear material released from damaged circulating cells, and presents negative regulation for the storage of lipids [48]. C-reactive protein is a marker of inflammation; in patients with diabetes, low-grade inflammation is evidenced by increased plasma levels [48]. However, in our study, animals in the DM1 + I group showed upregulation of this protein, which could also be associated with a decreased risk of cardiovascular disease in diabetes. The presence of $\mathrm{Cu}, \mathrm{Mg}$, Se, and $\mathrm{Zn}$ was not observed in this protein.

Apolipoprotein A-I (-DM/+DM1 + I) is part of the reverse transport of cholesterol from the tissues to the liver for excretion, by promoting cholesterol efflux from tissues and acting as a cofactor for lecithin cholesterol acyltransferase. Some studies have reported lower levels of apolipoprotein A-I in the presence of coronary complications [49]. The hyperglycemia observed in type 1 diabetes is closely related to lipidemic disorders, such as increased LDL cholesterol and triglycerides and reduced HDL cholesterol, which increase the risk of ischemic heart disease. Thus, the reduction of hyperglycemia that was observed in the animals of group DM1 + I has been found to be beneficial as a determining factor for decreased oxidative stress and reduced diabetic atherogenesis; in turn, this protein was upregulated in these animals [49]. In this protein, the presence of $\mathrm{Cu}$ was found in $\mathrm{C}$ and DM1 + I, and Cu and Mg in DM1.

\section{Conclusion}

Thirty-five proteins showed differential expression in plasma, indicating that alpha-1-macroglobulin and haptoglobulin may be potential candidates as biomarkers for controlled diabetes (treated with insulin), because significant changes were detected in this group, indicating a potential side effect of insulin treatment itself. Proteins such as $2^{\prime}$-deoxynucleoside $5^{\prime}$-phosphate $N$-hydrolase 1 , transmembrane protein 11 , serum amyloid P component, vitamin D-binding protein, and biliverdin reductase may be potential candidates as biomarkers for uncontrolled diabetes; these proteins changed in the diabetic group and did not maintain the same profile in the diabetic group treated with insulin. The proteins showed different interactions with $\mathrm{Cu}, \mathrm{Mg}$, Se, and $\mathrm{Zn}$, suggesting how bonds are altered in type 1 diabetes in plasma and revealing new functional aspects that may be involved in diabetes progression and protein expression.

\section{References}

[1] I. Pietrzak, B. Mianowska, A. Zmyslowska, W. Fendler, W. Mlynarski, A Szadkowska, Epidemiology and clinical course of diabetic ketoacidosis in children and adolescents with type 1 diabetes mellitus, Pediatr. Endocrinol. Diabetes Metab. 19 (2013) 137-142.

[2] American Diabetes Association, Standards of medical care in diabetes-2013, Diabetes Care 36 (2013) S11-S66.

[3] E.A.M. Gale, Type 1 diabetes in the young: the harvest of sorrow goes on, Diabetologia 48 (2005) 1435-1438.

[4] V. Harjutsalo, L. Sjöberg, J. Tuomilehto, Time trends in the incidence of type 1 diabetes in Finnish children: a cohort study, Lancet 371 (2008) 1777-1782.

[5] H.A. Keenan, J.K. Sun, J. Levine, A. Doria, L.P. Aiello, G. Eisenbarth, S. Bonner-Weir, G.L. King, Residual insulin production and pancreatic beta-cell turnover after 50 years of diabetes: Joslin Medalist Study, Diabetes 59 (2010) 2846-2853.

[6] S.Y. Hsieh, R.K. Chen, Y.H. Pan, H.L. Lee, Systematical evaluation of the effects of sample collection procedures on low-molecular-weight serum/plasma proteome profiling, Proteomics 6 (2006) 3189-3198.

[7] A.J. Rai, C.A. Gelfand, B.C. Haywood, D.J. Warunek, J. Yi, M.D. Schuchard, R.J. Mehigh, S.L. Cockrill, G.B.I. Scott, H. Tammen, P. Schulz-Knappe, D.W. Speicher, F. Vitzthum, B.B. Haab, G. Siet, D.W. Chan, HUPO Plasma Proteome 
Project specimen collection and handling: towards the standardization of parameters for plasma proteome samples, Proteomics 5 (2005) 3262-3277.

[8] J.L. Luque-Garcia, T.A. Neubert, Sample preparation for serum/plasma profiling and biomarker identification by mass spectrometry, J. Chromatogr. A 1153 (2007) 259-276.

[9] M.A. Atkinson, G.S. Eisenbarth, A.W. Michels, Type 1 diabetes, Lancet 383 (2014) 69-82.

[10] V. Gopalakrishnan, P. Purushothaman, A. Bhaskar, Proteomic analysis of plasma proteins in diabetic retinopathy patients by two dimensional electrophoresis and MALDI-Tof-MS, J. Diabetes Complication 29 (2015) 928-936.

[11] S.-X. Zhang, H. Sun, W.-J. Sun, G.-Z. Jiao, X.J. Wang, Proteomic study of serum proteins in a type 2 diabetes mellitus rat model by chinese traditional medicine Tianqi Jiangtang Capsule administration, J. Pharm. Biomed. Anal. 53 (2010) 1011-1014.

[12] A. Vlahou, M. Fountoulakis, Proteomic approaches in the search for disease biomarkers, J. Chromatogr. B 814 (2005) 11-19.

[13] W. Shi, M.R. Chance, Metalloproteomics: forward and reverse approaches in metalloprotein structural and functional characterization, Curr. Opin. Chem. Biol. 15 (2011) 144-148.

[14] W. Shi, C. Zhan, A. Ignatov, B.A. Manjasetty, N. Marinkovic, M. Sullivan, R. Huang, M.R. Chance, Metalloproteomics: high-throughput structural and functional annotation of proteins in structural genomics, Structure 13 (2005) $1473-1486$

[15] R.A. Moura, A. Purchio, A.L.R. Rossi, B. Struffaldi, D.M. Nogueira, G. Hoxter, C.J. Oliveira, T.V. Almeida, Técnicas de laboratório, 1982.

[16] A. Shevchenko, H. Tomas, J. Havlis, J.V. Olsen, M. Mann, In-gel digestion for mass spectrometric characterization of proteins and proteomes, Nat. Protoc. 1 (2006) 2856-2860

[17] G.Z. Li, J.P.C. Vissers, J.C. Silva, D. Golick, M.V. Gorenstein, S.J. Geromanos, Database searching and accounting of multiplexed precursor and product ion spectra from the data independent analysis of simple and complex peptide mixtures, Proteomics 9 (2009) 1696-1719.

[18] A. Conesa, S. Gotz, Blast2GO: a comprehensive suite for functional analysis in plant genomics, Int. J. Plant Genom. 2008 (2008).

[19] P.M. Moraes, F.A. Santos, B. Cavecci, C.C.F. Padilha, J.C.S. Vieira, P.S. Roldan, P.D.M. Padilha, GFAAS determination of mercury in muscle samples of fish from Amazon, Brazil, Food Chem. 141 (2013) 2614-2617.

[20] J.H. Zar, Biostatistical Analysis, 2010.

[21] T.M. Devlin, Textbook of Biochemistry with Clinical Correlations, seven ed. Wiley-Liss, New York, 2011.

[22] E. Barth, G. Albuszies, K. Baumgart, M. Matejovic, U. Wachter, J. Vogt, P. Radermacher, E. Calzia, Glucose metabolism and catecholamines, Crit. Care Med. 35 (2007) S508-S518.

[23] R. Chawla, Manual of Diabetes Care, JP Medical Ltd., 2014.

[24] M. Laclaustra, A. Navas-Acien, S. Stranges, J.M. Ordovas, E. Guallar, Serum selenium concentrations and diabetes in U.S. adults: National health and nutrition examination survey (NHANES) 2003-2004, Environ. Health Perspect. 117 (2009) 1409-1413.

[25] J. Bleys, A. Navas-Acien, E. Guallar, Serum selenium and diabetes in U.S. adults, Diabetes Care 30 (2007) 829-834.

[26] W.T. Morgan, Histidine-rich glycoprotein, Encycl. Mol. Med. (2002), http://dx. doi.org/10.1002/0471203076.emm0690/full.

[27] W.T. Morgan, Interactions of the histidine-rich glycoprotein of serum with metals, Biochemistry 20 (1981) 1054-1061.

[28] A. Abrieu, L. Magnaghi-Jaulin, J.A. Kahana, M. Peter, A. Castro, S. Vigneron, T. Lorca, D.W. Cleveland, J.C. Labbé, Mps1 is a kinetochore-associated kinase essential for the vertebrate mitotic checkpoint, Cell 106 (2001) 83-93.

[29] K. Yamamoto, Y. Suzuki, H. Sinohara, Synthesis of contrapsin and alpha-1-antiproteinase in inflamed and tumor-bearing mice, Biochem. Int. 16 (1988) 921-928.
[30] N. Aminudin, N.-A.H. Abdullah, H. Misbah, S. a Karsani, R. Husain, S.Z. Hoe O.H. Hashim, Treatment with captopril abrogates the altered expression of alpha1 macroglobulin and alpha1 antiproteinase in sera of spontaneously hypertensive rats, Proteome Sci. 10 (2012) 17.

[31] C. Amiable, S. Pochet, A. Padilla, G. Labesse, P.A. Kaminski, N6-substituted AMPs inhibit mammalian deoxynucleotide N-hydrolase DNPH1, PLoS One 8 (2013).

[32] G.J. Kato, C.V. Dang, Function of the c-Myc oncoprotein, FASEB J. 6 (1992) 3065-3072

[33] G. Wolf, K. Sharma, Y. Chen, M. Ericksen, F.N. Ziyadeh, High glucose-induced proliferation in mesangial cells is reversed by autocrine TGF-beta, Kidney Int. 42 (1992) 647-656.

[34] H. Inoue, Y. Tanizawa, J. Wasson, P. Behn, K. Kalidas, E. Bernal-Mizrachi, M. Mueckler, H. Marshall, H. Donis-Keller, P. Crock, D. Rogers, M. Mikuni, H. Kumashiro, K. Higashi, G. Sobue, Y. Oka, M.A. Permutt, A gene encoding a transmembrane protein is mutated in patients with diabetes mellitus and optic atrophy (Wolfram syndrome), Nat. Genet. 20 (1998) 143-148.

[35] S. Marinković, H. Baumann, Structure hormonal regulation, and identification of the interleukin-6- and dexamethasone-responsive element of the rat haptoglobin gene, Mol. Cell. Biol. 10 (1990) 1573-1583.

[36] G. Paz-Filho, C. Mastronardi, C.B. Franco, K.B. Wang, M.-L. Wong, J. Licinio, Leptin: molecular mechanisms, systemic pro-inflammatory effects, and clinical implications, Arq. Bras. Endocrinol. Metabol. 56 (2012) 597-607.

[37] T. Bartfai, T.G. Hökfelt, Ü. Langel, Galanin - a neuroendocrine peptide, Crit. Rev. Neurobiol. 7 (1993) 229-274.

[38] P.T.W. Cohen, Protein phosphatase 1-targeted in many directions, J. Cell Sci. 115 (2002) 241-256

[39] M.C. Bickerstaff, M. Botto, W.L. Hutchinson, J. Herbert, G.A. Tennent, A. Bybee, D.A. Mitchell, H.T. Cook, P.J. Butler, M.J. Walport, M.B. Pepys, M.C.M.B. Ickerstaff, M.B. Otto, W.L.H. Utchinson, J.H. Erbert, G.A.T. Ennent, Serum amyloid $\mathrm{P}$ component controls chromatin degradation and prevents antinuclear autoimmunity, Nat. Med. 5 (1999) 694-697.

[40] R.A. Clark, B.D. Volpp, K.G. Leidal, W.M. Nauseef, Two cytosolic components of the human neutrophil respiratory burst oxidase translocate to the plasma membrane during cell activation, J. Clin. Invest. 85 (1990) 714-721.

[41] P. White, N. Cooke, The multifunctional properties and characteristics of vitamin D-binding protein, Trends Endocrinol. Metab. 11 (2000) 320-327.

[42] N. Lerner-Marmarosh, J. Shen, M.D. Torno, A. Kravets, Z. Hu, M.D. Maines, Human biliverdin reductase: a member of the insulin receptor substrate family with serine/threonine/tyrosine kinase activity, Proc. Natl. Acad. Sci. 102 (2005) 7109-7114.

[43] A.S. Pachori, A. Smith, P. McDonald, L. Zhang, V.J. Dzau, L.G. Melo, Heme-oxygenase-1-induced protection against hypoxia/reoxygenation is dependent on biliverdin reductase and its interaction with PI3K/Akt pathway, J. Mol. Cell. Cardiol. 43 (2007) 580-592.

[44] K. Ueki, C.M. Yballe, S.M. Brachmann, D. Vicent, J.M. Watt, C.R. Kahn, L.C Cantley, Increased insulin sensitivity in mice lacking p85beta subunit of phosphoinositide 3-kinase, Proc. Natl. Acad. Sci. 99 (2002) 419-424.

[45] C.H. Lu, S.T. Lin, H.C. Chou, Y.R. Lee, H.L. Chan, Proteomic analysis of retinopathy-related plasma biomarkers in diabetic patients, Arch. Biochem. Biophys. 529 (2013) 146-156.

[46] G. Eggertsen, G. Hudson, B. Shiels, D. Reed, G.H. Fey, Sequence of rat alpha 1-macroglobulin, a broad-range proteinase inhibitor from the alpha-macroglobulin-complement family, Mol. Biol. Med. 8 (1991) 287-302.

[47] E. Burgos-Ramos, L. Sackmann-Sala, E. Baquedano, D. Cruz-Topete, V. Barrios, J. Argente, J.J. Kopchick, Central leptin and insulin administration modulates serum cytokine- and lipoprotein-related markers, Metabolism 61 (2012) 1646-1657.

[48] S.B. Rosalki, C-reactive protein, Int. J. Clin. Pract. 55 (2001) 269-270.

[49] A.V. Khera, M. Cuchel, M. de la Llera-Moya, A. Rodrigues, M.F. Burke, K. Jafri, B.C. French, J.A. Phillips, M.L. Mucksavage, R.L. Wilensky, E.R. Mohler, G.H. Rothblat, D.J. Rader, Cholesterol efflux capacity high-density lipoprotein function, and atherosclerosis, N. Engl. J. Med. 364 (2011) 127-135. 